\title{
Analisis Perlakuan Akuntansi atas Pendapatan dan Beban Berbasis SAK ETAP dan Implikasinya pada Laporan Keuangan Koperasi Simpan Pinjam Estu Mulya Sukodadi Lamongan
}

\author{
Sutri Handayani \\ sutrihandayani99@gmail.com \\ Fakultas Ekonomi Universitas Islam Lamongan
}

\begin{abstract}
Abstrak
Koperasi simpan pinjam merupakan jenis usaha yang sangat mengandalkan kepercayaan masyarakat untuk menunjang perkembangan dan kelangsungan usahanya. Masalah yang hendak dicari jawabannya dalam penelitian ini adalah bagaimana perlakuan akuntansi atas pendapatan dan beban pada laporan keuangan pada Koperasi Simpan Pinjam Estu Mulyayang sesuai dengan SAK ETAP.Hasil analisis menunjukkan bahwa pendapatan berdasarkan KSP Estu Mulya sebesar Rp 2.750.300.790,- sedangkan pendapatan berdasarkan SAK ETAP diakui sebesar Rp 3.300.361.000,- hasil ini diperoleh dari pendapatan bunga dikalikan $10 \%$ dan dikalikan dengan jumlah bulan dalam satu periode. Metode analisis data yang digunakan adalah mengumpulkan data mengenai subyek penelitian untuk memahami latar belakang dari KSP Estu Mulya, menganalisis perlakuan akuntansi dalam menyusun pendapatan dan beban dengan basis SAK ETAP, menulis laporan hasil penelitian, dan menarik kesimpulan terhadap rumusan masalah dan memberikan saran pengembangan implementasi hasil penelitian. Kesimpulan dari penelitian ini adalah pengakuan pendapatan belum sesuai dengan SAK ETAP,sedangkan untuk pengakuan beban sudah sesuai.
\end{abstract}

Kata kunci : perlakuan akuntansi, pendapatan, beban

\section{PENDAHULUAN}

Pembangunan yang dilaksanakan bangsa Indonesia merupakan wujud dari usaha untuk mencapai tujuan nasional. Tujuan nasional bangsa Indonesia tercermin dalam Undang - Undang Dasar 1945. Dalam bidang ekonomi pasal 33 ayat 1 menyatakan bahwa "Perekonomian disusun sebagai usaha bersama berdasarkan atas asas kekeluargaan". Dalam penjelasan UndangUndang Dasar 1945 disebutkan bahwa usaha yang sesuai dengan pasal tersebut adalah koperasi. Koperasi sebagai suatu sistem yang turut serta mewarnai kehidupan perekonomian Indonesia telah memiliki legalitas tersendiri yang tertuang dalam Undang- Undang No.25 tahun 1992.

Koperasi merupakan organisasi yang terbuka, terutama bagi para anggotanya. Pembangunan koperasi sebagai badan usaha ditujukan pada penguatan dan perluasan basis usaha, peningkatan mutu sumber daya manusia terutama pengurus, pengelola dan 
anggotanya berakhlak mulia, termasuk kewirausahaan profesionalisme koperasi, sehingga dengan kinerja yang makin sehat, kompetitif dan mandiri, koperasi mampu menjadi bangun usaha utama dalam perekonomian.

Dalam sejarah perkembangan perekonomian di Indonesia, koperasi memiliki peranan penting. Berkembangnya Koperasi sebagai usaha masyarakat mampu memperkuat dirinya sebagai badan usaha yang tangguh dan mandiri. Koperasi juga berlandaskan pada prinsip-prinsip Koperasi, sekaligus gerakan ekonomi rakyat yang berdasarkan atas asas kekeluargaan.

Tetapi pada kenyataannya, koperasi yang disebut-sebut sebagai sokoguru perekonomian nasional, ternyata belum dapat mewujudkan kemampuan dan peranannya secara optimal dalam berpartisipasi dalam perekonomian Indonesia. Selain itu, kekurangan yang dihadapi koperasi terutama adalah akibat keterbatasan sumberdaya yang meliputi manajerial, modal akses kredit yang tidak merata maupun adanya pembatasan kredit, perencanaan, administrasi dan sumber daya manusia.

Dengan adanya keterbatasanketerbatasan tersebut, koperasi akan memberikan peluang perbaikan yang begitu luas. Perbaikan ini diharapkan untuk mengembangkan koperasi menjadi maju, mandiri, dan berakar dalam masyarakat. Salah satu perbaikan yang dilakukan adalah dalam bidang manajerial untuk menciptakan koperasi sebagai badan usaha yang efisien, efektif, dan ekonomis. Dalam hal ini, akuntansi dapat berperan untuk memberikan perbaikan dalam bidang manajerial.

Berdasarkan Undang-Undang No 17 tahun 2012, Koperasi adalah badan hukum yang didirikan oleh orang perseorangan atau badan hukum Koperasi,dengan pemisahan kekayaan para anggotanya sebagai modal untuk menjalankan usaha, yang memenuhi aspirasi dan kebutuhan bersama di bidang ekonomi, sosial, dan budaya sesuai dengan nilai dan prinsip koperasi.

Muhammad Khafid, dkk. (2010) mengatakan bahwa, untuk mencapai tujuantujuan koperasi, maka pengelolaan koperasi harus dilakukan dengan benar dan profesional. Salah satu tolak ukur koperasi yang sehat adalah koperasi yang melakukan pengelolaan keuangan yang benar. Sebagai sebuah lembaga ekonomi yang menghasilkan suatu laporan keuangan maka masalah akuntansi koperasi merupakan salah satu masalah penting yang ada di koperasi.

Menurut Rudianto (2010), koperasi simpan pinjam adalah koperasi yang hanya menjalankan satu usaha yaitu penghimpunan dan penyaluran dana kepada masyarakat.

Penyusunan laporan keuangan koperasi hendaknya berpedoman pada standar akuntansi keuangan untuk entitas tanpa akuntabilitas publik. SAK ETAP terpisah dari SAK besar dimana SAK ETAP dalam pedoman penyusunan laporan keuangan dibuat lebih sederhana. Selain itu diterbitkannya SAK ETAP sendiri bertujuan untuk memudahkan pengusaha kecil atau menengah untuk menyusun laporan keuangan sendiri sehingga dapat berguna bagi intern atau untuk mendapatkan dana.

Menurut Achmad Ramadhani (2010), dalam beberapa hal SAK ETAP memberikan banyak kemudahan untuk perusahaan dibandingkan dengan PSAK dengan ketentuan pelaporan yang lebih kompleks. Latar belakang disusunnya SAK ETAP yang terpisah dari PSAK adalah karena PSAK (Pernyataan Standar Akuntansi Keuangan) yang mengadopsi International Financial Reporting Standard (IFRS) terlalu kompleks jika diterapkan oleh usaha kecil di Indonesia. Maka dari itu 
diperlukan standar yang lebih sederhana dan memudahkan usaha kecil dalam penyusunan laporan keuangan.

Rumusan masalah pada penelitian ini adalah Bagaimana perlakuan akuntansi atas pendapatan dan beban pada laporan keuangan pada Koperasi Simpan Pinjam Estu Mulya yang sesuai dengan SAK ETAP?

\section{KAJIAN PUSTAKA}

Menurut Mardiasmo ( 2008 : 1 ) Akuntansi adalah seni pencatatan, penggolongan, peringkasan, dan pelaporan transaksi-transaksi keuangan suatu organisasi dengan cara-cara tertentu yang sistematis, serta penafsiran terhadap hasilnya.

Menurut Mardiasmo (2008 : 43) pendapatan adalah peningkatan jumlah aktiva atau penurunan kewajiban perusahaan, yang timbul dari penyerahan barang / jasa atau kegiatan usaha yang lain didalam satu periode akuntansi. Tidak termasuk dalam pengertian pendapatan adalah peningkatan aktiva atau penurunan kewajiban perusahaan yang timbul dari pembelian harta, investasi oleh pemilik diperolehnya pinjaman, dan koreksi laba/rugi periode yang lalu.

IAI (2013: 6 ) menjelaskan tentang pendapatan adalah suatu penghasilan yang timbul dalam pelaksanaan aktivitas entitas yang biasa dan dikenal dengan sebutan yang berbeda seperti penjualan, imbalan, bunga, deviden, royalti dan sewa.

Beban merupakan konsep arus yang menggambarkan perubahan yang tidak menguntungkan sumber daya perusahaan. Beban timbul akibat adanya aktivitas perusahaan yang biasanya terbentuk pada arus kas atas berkurangnya aset seperti kas dan setara kas, persediaan serta aset tetap. Definisi beban berkaitan dengan kerugian, karena beban merupakan arus keluar harta atau timbulnya hutang atau keduanya selama satu periode sebagai akibat dari penyerahan atau produksi barang, pemberian jasa, aktivitas yang mendatangkan keuntungan lainnya yang merupakan operasi utama satu entitas. Karakteristik utama beban terjadi di dalam proses pembentukan pendapatan (Suwardjono, 2006).

Menurut Mardiasmo ( 2008 : 44 ) beban adalah pengorbanan ekonomis yang diperlukan untuk memperoleh barang atau jasa. Pengorbanan ekonomis tersebut dapat berupa pengurangan aktiva atau pertambahnya utang dan modal perusahaan.

\section{METODE PENELITIAN}

Metode Pengumpulan Data, Jenis Data adalah Data Sekunder (Data yang dicatat dari obyek penelitian buku bacaan atau yang berhubungan dengan masalah yang akan dibahas peneliti dalam sebuah penelitiannya dalam penyusunan data) dan Data Primer (Data yang diperoleh dari penelitian dan diolah oleh peneliti dengan cara wawancara. Seperti data populasi, sejarah perusahaan dan struktur organisasi perusahaan ).

Sedangkan data yang digunakan dalam penelitian ini adalah Data kualitatif dan Data kuantitatif, adapun pengertiannya adalah Data Kualitatif ( Data tersebut berupa keadaan dan gambaran umum koperasi serta hasil konfirmasi dari pengurus koperasi yang menjadi obyek penelitian ), dan Data Kuantitatif ( Data berupa laporan keuangan yang meliputi laporan keuangan sisa hasil usaha, laporan arus kas, laporan promosi ekonomi anggota dan Catatan Atas Laporan Keuangan ).

Dilihat dari rumusan masalah dan tujuan penelitian, penelitian ini tergolong penelitian deskriptif kualitatif dimana penelitian ini bertujuan untuk mendeskripsikan perlakuan akuntansi atas 
pendapatan dan beban berbasis SAK ETAP yang ada pada Koperasi Simpan Pinjam. Dengan menggunakan metode deskriptif yang merupakan penyajian dari data yang didapatkan sebagai hasil penelitian dengan memberikan gambaran menurut apa adanya sesuai dengan kenyataan pada waktu mengadakan penelitian.

Hasil penelitian selanjutnya dibandingkan dengan kriteria-kriteria yang digunakan, dalam hal ini SAK ETAP mengenai akuntansi perkoperasian serta dianalisis dan diolah untuk mendapatkan pemecahan dan kesimpulan sehingga mampu memberikan saran-saran dan pertimbangan demi perbaikan koperasi tersebut dikemudian hari. Metode Analisis Data yang digunakan adalah mengumpulkan data mengenai subyek penelitian untuk memahami latar belakang dari Koperasi Simpan Pinjam Estu Mulya Sukodadi Lamongan, menganalisis perlakuan akuntansi dalam menyusun pendapatan dan beban dengan basis SAK ETAP, menulis laporan hasil penelitian, dan menarik kesimpulan terhadap rumusan masalah dan memberikan saran pengembangan implementasi hasil penelitian.

\section{HASIL DAN PEMBAHASAN}

Standar Akuntansi untuk Koperasi Simpan Pinjam " Estu Mulya " berdasarkan Buletin Teknis 6 yang ditetapkan oleh Dewan Standar Akuntansi Keuangan ( DSAK ) yang dikeluarkan pada tanggal 11 Agustus 2011 menyatakan bahwa entitas yang memenuhi syarat untuk menerapkan SAK ETAP adalah entitas yang tidak memiliki akuntabilitas publik signifikan dan menerbitkan laporan keuangan untuk tujuan umum bagi pengguna eksternal. Hal ini kembali diatur dan dijelaskan pada Bab 1 SAK ETAP tentang ruang lingkup. Berdasarkan ketetapan ini, dapat disimpulkan bahwa ada dua syarat penting bagi suatu entitas agar dapat menjadikan SAK ETAP sebagai standar akuntansi yang diterapkan dalam laporan keuangan yang akan disajikan, yaitu mengenai akuntabilitas publik dan tujuan penerbitan laporan keuangan.

Koperasi Simpan Pinjam “ Estu Mulya " yang berdiri pada tahun 1997 menjalankan kegiatan intermediasi dana dengan mengumpulkan dana dari seluruh anggota koperasi dalam bentuk tabungan maupun investasi berjangka untuk kembali didistribusikan kepada anggota yang membutuhkan dana pinjaman. Berdasarkan hal ini terlihat jelas bahwa KSP “ Estu Mulya " memiliki akuntabilitas publik yang signifikan karena juga belum mendaftarkan diri sebagai perusahaan publik. Sehingga KSP “ Estu Mulya " hanya bertanggung jawab atas dana anggota - anggotanya. Untuk pendapatan sesuai dengan paragraf 2.36 SAK ETAP dijelaskan bahwa pengakuan penghasilan merupakan akibat langsung dari pengakuan aset dan kewajiban yang merupakan komponen Neraca.

Penghasilan diakui dalam laporan laba rugi jika kenaikan manfaat ekonomi di masa depan yang berkaitan dengan peningkatan aset atau penurunan kewajiban telah terjadi dan dapat diukur secara andal. Dalam penyajian Koperasi “ Estu Mulya “ membagi pendapatan menjadi lebih rinci berdasarkan jenis jasa yang diberikan. Perincian ini diperbolehkan oleh SAK ETAP sesuai dengan pernyataan paragraf 5.4 karena penyajian rincian ini memberikan informasi yang relevan untuk lebih memahami kinerja koperasi dalam peride tersebut.

Sedangkan untuk beban menurut SAK ETAP paragraf 5.6, beban haruslah diklasifikasikan lebih lanjut berdasarkan 
sifat atau fungsi beban. Akan tetapi, dalam paragraf 5.8 disebutkan bahwa entitas yang mengklasifikasikan beban berdasarkan fungsi mengungkapkan informasi tambahan berdasarkan sifat beban, termasuk penyusutan dan beban amortisasi dan beban imbalan kerja. Hal ini telah diterapkan dengan baik oleh Koperasi " Estu Mulya ". Koperasi "Estu Mulya " mengklasifikasikan beban menurut fungsinya dan kemudian memberikan informasi lebih lanjut mengenai sifat beban melalui subklasifikasi pada masing - masing beban menurut fungsi tersebut.

Pengakuan dan pengukuran pendapatan bunga pinjaman pada KSP “ Estu Mulya " belum sesuai dengan SAK ETAP. Pendapatan bunga pinjaman pada Koperasi Simpan Pinjam "Estu Mulya" tahun 2014 yaitu diakui sebesar Rp 2.750.300.790,- pengukuran pendapatan bunga pinjaman pada Koperasi Simpan Pinjam " Estu Mulya “ ditetapkan 10 \% dari pinjaman yang diberikan.

Berikut adalah rumus penghitungan berdasarkan SAK ETAP :

\section{Pendapatan Bunga $x$ persentase $(\%)$ $x$ jumlah bulan dalam satu periode}

Penghitungan pendapatan berdasarkan koperasi adalah pendapatan dikalikan dengan prosentase bunga sebesar $10 \%$. Sedangkan jika disesuaikan dengan Standar Akuntansi Keuangan Entitas Tanpa Akuntabilitas Publik ( SAK ETAP ) pendapatan bunga pinjaman diakui secara akrual, dimana pencatatan bunga pinjaman kedalam rekening pendapatan pada saat jatuh waktu sebesar persentase yang ditetapkan dari jumlah pinjaman yang diberikan dikalikan dengan jumlah bulan dalam satu periode, maka hasilnya menjadi
Rp 3.300.361.000,- Pengakuan dan pengukuran pendapatan provisi dan biaya administrasi yang diterapkan KSP “ Estu Mulya "belum sesuai SAK ETAP.

Pendapatan jasa administrasi yang terdiri dari pendapatan provisi dan pendapatan dari biaya transaksi atas jasa pinjaman yang diberikan. Berdasarkan AD / ART koperasi pendapatan jasa administrasi yang diterapkan oleh KSP " Estu Mulya “ ditetapkan $15 \%$ dari jumlah pinjaman yaitu $10 \%$ untuk pendapatan provisi dan $5 \%$ untuk biaya transaksi. Pendapatan jasa administrasi pada KSP "Estu Mulya " diakui pada saat realisasi kredit dan tidak diamortisasi yang dinilai sebesar Rp 438.774.000,--

Sedangkan menurut SAK ETAP pendapatan provisi diakui pada saat pinjaman diberikan yang ditangguhkan terlebih dahulu kemudian diamortisasi secara sistematis sesuai dengan jangka waktu kredit, sehingga pada koperasi ini pendapatan provisi setelah dihitung berdasarkan SAK ETAP menjadi Rp 36.564.500,-.

Untuk pengakuan dan pengukuran beban bunga simpanan yang diterapkan oleh KSP " Estu Mulya " sudah sesuai dengan SAK ETAP. Beban bunga simpanan pada KSP "Estu Mulya " diakui sesuai dengan periode waktu jatuh temponya, artinya beban bunga atas simpanan untuk bulan desember sudah diakui dan langsung dicatat sebagai penambah simpanan anggota yang bersangkutan melalui jurnal umum ataupun jurnal penyesuaian. Beban bunga simpanan sukarela dinilai sebesar $\mathrm{Rp}$ 214.214.450,beban bunga simpanan berjangka dinilai sebesar Rp 825.778.500,- beban bunga simpanan berjenjang dinilai sebesar $\mathrm{Rp}$ 5.450.000,- dan beban bunga simpanan saham dinilai sebesar Rp 780.500.095,-- 
Pengakuan dan pengukuran beban operasional yang diterapkan KSP “ Estu Mulya "sudah sesuai dengan SAK ETAP. Beban operasional lainnya pada KSP "Estu Mulya " diakui sebesar jumlah yang menjadi kewajiban koperasi. Beban personalia yaitu berkaitan dengan pemberian imbalan kerja diakui pada saat pegawai telah memberikan jasanya yang dinilai sebesar Rp 450.704.273,- beban administrasi dan umum dinilai sebesar $\mathrm{Rp}$ 386.287.489,- beban penyusutan aktiva tetap dinilai sebesar $\mathrm{Rp}$ 62.300.773,--

Pengakuan dan pengukuran beban non-operasional lainnya pada KSP " Estu Mulya " sudah sesuai dengan SAK ETAP. Beban non-operasional lainnya pada KSP “ Estu Mulya " diakui pada saat terjadinya, diukur sebesar jumlah yang harus diselesaikan koperasi yang dinilai sebesar Rp 3.500.707,-.

Beban pajak sesuai perhitungan SAK ETAP adalah sebesar Rp. 448.278.900,-. Nilai tersebut diperoleh berdasarkan perhitungan pph badan sesuai dengan Tarif Pajak PPh Badan untuk Tahun Pajak 2013 berdasarkan Pasal 17 dan Pasal 31 E Undang-Undang No.36 Tahun 2008 Tentang Pajak Penghasilan Undang-Undang No. 36 tahun 2008 tentang pajak penghasilan, ditetapkan $25 \%$ dari penghasilan kena pajak, dan untuk entitas dengan peredaran bruto sampai dengan $\mathrm{Rp}$ 50.000.000.000 akan mendapat fasilitas berupa pengurangan tarif sebesar 50 persen.

Sedangkan Penghitungan Pajak penghasilan yang terhutang pada koperasi adalah :

$$
\begin{aligned}
& =50 \% \text { x } 25 \% \text { x Rp 3.586.231.528,- } \\
& =12,5 \% \times \operatorname{Rp} 3.586 .231 .528,- \\
& =\operatorname{Rp} 448.278 .900,-
\end{aligned}
$$

\section{KESIMPULAN DAN SARAN 5.1. KESIMPULAN}

Berdasarkan pembahasan diatas dapat ditarik kesimpulan bahwa pada koperasi belum sepenuhnya menggunakan PSAK ETAP , dilihat dari pengakuan pendapatan yang ternyata belum diakui secara akrual, tetapi untuk pengakuan beban pada koperasi ini semuanya sudah sesuai dengan SAK ETAP.

\subsection{SARAN}

Untuk Koperasiagar melakukan penerapan standar akuntansi entitas tanpa akuntanbilitas publik (SAK ETAP) sebagai acuan dalam penyusunan laporan keuangan koperasi. Khususnya pada pengakuan pendapatan yang ada pada Laporan Sisa Hasil Usaha ( SHU ). Hal ini dilakukan agar laporan keuangan jelas dan memberikan informasi penuh terhadap kondisi keuangan koperasi.Sedangkan untuk Peneliti Selanjutnyaharus lebih memahami apa itu SAK ETAP dan bagaimana perlakuannya serta penerapannya pada koperasi, agar dapat dengan mudah menyelesaikan masalah yang sesuai dengan judul yang anda buat.

\section{DAFTAR PUSTAKA}

IAI.(2013).SAK ETAP. Cetakan Ketiga. Ikatan Akuntansi Indonesia.

Khafid, Muhammad, dkk. (2010). Analisis PSAK No. 27 Tentang Akuntansi Perkoperasian dan Pengaruhnya terhadap Kesehatan Usaha pada KPRI. Dalam Jurnal Dinamika Akuntansi, 2(1): h:37-45.

Mardiasmo.(2008).Akuntansi Keuangan Dasar. Edisi Ketiga. Cetakan Kedua. Yogyakarta : Anggota IKAPI.

Ramdhani, Achmad. (2015). Analisis Penerapan PSAK No.46 Terhadap 
Penyajian Laporan Keuangan pada PT. Mitra Tritunggal Abadi, http://repository.unhas.ac.id/handle/1 23456789/125

Rudianto.(2010). Akuntansi Koperasi, Erlangga: Jakarta.

Suwardjono.(2006).Teori Akuntansi. Edisi Ketiga. Cetakan Kedua. Yogyakarta : Fakultas Ekonomika Universitas Gadjah Mada.
UUD Republik Indonesia, Nomer 17 Tahun 2012 Tentang Perkoperasian.

UUD Republik Indonesia, Nomor 25 Tahun 1992 Tentang Perkoperasian.

UUD (1945) Pasal 33. Nasionalisasikan Sumber Daya Alam Indonesia Demi Kesejahteraan Bangsa. 01 Maret 2019. 